\title{
Problem-based Learning Method: Secondary Education 10th Grade Chemistry Course Mixtures Topic
}

\author{
Musa Üce ${ }^{1}$, İsmail Ateş ${ }^{1}$ \\ ${ }^{1}$ Marmara University, Faculty of Education, Department of Educational Science and Mathematics, Istanbul, Turkey \\ Correspondence: Musa Üce, Marmara University, Faculty of Education, Department of Educational Science and \\ Mathematics, Istanbul, Turkey.
}

Received: September 23, 2016

Accepted: October 7, $2016 \quad$ Online Published: October 21, 2016

doi:10.11114/jets.v4i12.1939

URL: http://dx.doi.org/10.11114/jets.v4i12.1939

\begin{abstract}
In this research; aim was determining student achievement by comparing problem-based learning method with teacher-centered traditional method of teaching 10th grade chemistry lesson mixtures topic. Pretest-posttest control group research design is implemented. Research sample includes; two classes of (total of 48 students) an Anatolian High School student in 2014-2015 academic year. Treatment took place for 16 hours. Experiment group treated with problem-based learning method, control group was treated with teacher-centered traditional method. Data was conducted with scientific achievement scale and t-test was used to analyse data. Findings showed that there was a significant difference between two groups in favour of students treated with problem-based teaching in terms of scientific achievements in mixtures topic.
\end{abstract}

Keywords: chemistry education, problem-based learning, mixtures topic

\section{Introduction}

Due to the fact that Chemistry course is taught mainly in theory, it is deemed as a difficult discipline with regard to the understanding of the topics by the students. Consequently, students suppose that chemistry has little contribution to the development of the society. However, in addition to its contribution to students' choices of profession, chemistry is an enjoyable course, which helps students understand the environment, world and universe they live in (Demircioğlu, Demircioğlu \& Ayas, 2006).

Constructivist approach reveals the necessity of preferring environments in which learning activities are more efficient and productive, and where students can express their opinions, perform applications, hold discussions on topics and listen to each other. Leading teaching approaches which provide such environments are learning models like cooperative, computer-aided, problem-based, project-based learning methods, case study, demonstration-performance, brainstorming, drama. It has been revealed through a wide range of scientific research that problem-based and cooperative learning methods improve individuals all-round academically, socially, psychologically etc. (Bayrakçeken, Doymuş \& Doğan, 2013).

Students' interests in topics fade away because of the fact that we do not exemplify the taught course topics, out of the environment we are in, of our daily lives and of the topic-related technologies which we use in order to facilitate our lives. Learned information cannot go beyond theory due to the fact that applications on the covered topic are not realized adequately. Thereby, usage frequency of rote-learning-based abstract expressions increases in the examinations, which are performed for assessment and evaluation. Due to these reasons, problem-based teaching method is considerably convenient to be used in chemistry subjects. Because students search for information in order to solve the problem, they process the retrieved information and absorb it as they arrange the learned information in their own way. Oblivion of information retrieved in this manner takes a long time (Chin \& Chia, 2004; Koray, Akyaz \& Köksal, 2007).

Problem-based Learning (PBL) was introduced in Case W. University School of Medicine in the United States of America in 1950s. PBL method was also applied in Canada McMaster University in the late 1960s. It takes its basis from the "learning by doing and living" method, which is one of the arguments of John Dewey (Barrows \& Tamblyn, 1980). In PBL, student gains experience by solving the problems in the environment he/she lives in and such experience ensures active learning. Active participation in lessons enables students to keep in mind and remember what they learned, for a longer period of time (Mierson \& Parikh, 2000). 
PBL method can also be defined as an education strategy, which assists students to achieve success in lessons, solve course-related problems and communicate with each other (Duch , 2001).In science lessons, PBL method helps students gain skills and learn scientific procedures like observation, measurement, communication, estimation, data acquisition, variable trace, hypothesizing, experiment planning and performing, model building etc. By taking responsibilities, students in the classes where PBL method is applied gain independence from their course teachers phase by phase and consequently they become independent learners throughout their education (Dahlgren \& Öberg, 2001; Kaptan \& Korkmaz, 2001).

One of the significant characteristics of PBL method is that students contribute to each other's learning concertedly by forming small heterogeneous groups, under the guidance of the teacher, for a common target. In order for a small-group activity to be a cooperative learning, students should make an effort to optimize both their own learning and the learning of the students in the group (Boud \& Feletti, 1991; Kaptan \& Korkmaz, 2001; Mc Donnell, O'Connor \& Seery, 2007; Akınoğlu \& Eren, 2013). Compared to traditional methods, teaching students in groups has a more positive effect on students' academic achievements and eagerness to learn (Springer, Stanne \& Donovan, 1999). Students studying in accordance with the scenarios which form the basis of the PBL method learn the prominent concepts of the lesson in a better way and they also acquire cooperative study skills and real life experience (Dahlgren \& Öberg, 2001).

In cooperative learning model, lessons have a student-centered feature where students are active under the guidance of the teacher. According to Doymuş, Şimşek and Bayrakçeken (2004), cooperative learning is a learning model where students in small groups help each other's learning of scientific topics for common targets, where they increase their self-confidence, where they improve their skills in communication and problem-solving and where they actively participate in the learning-teaching process.

A wide range of national and international databases have been scanned during the literature searching process; however it has been detected that there is insufficient number of research in the related literature regarding the studies of problem-based learning for mixtures topics in secondary education. This case is considered to be quite remarkable. In fact, discussing the mixtures topic through problem-based learning method may affect the achievement level in class positively. From this point of view, and in consideration of the above-mentioned literature, the purpose of this study is searching whether there is differentiation between the academic success of students who receive education through problem-based learning method and teacher-based traditional method for the solutions of real-life problems in the topic of mixtures. Besides, it is expected that data revealed at the end of this research will contribute to the chemistry education program and to the content of the course books in secondary education.

\section{Method}

Out of the experimental research designs, pretest-posttest design with control group was used in the research. The topic of mixtures was discussed through the problem-based learning method in the experimental group, and through the teacher-centered traditional teaching method in the control group.

\subsection{Research Group}

Forty eight $10^{\text {th }}$-grade students in total, who received education in 2014-2015 academic year in two different classes at Anatolian High School located in the city of Istanbul, constituted the research group. When the groups were chosen, $9^{\text {th }}$ grade's chemistry lesson's school report points were taken into consideration and one of the groups was randomly selected as the experimental group while the other was chosen as the control group.

\subsection{Data Gathering Tools}

\subsubsection{Mixtures Achievement Test}

A two-stage multiple-choice test composed of 30 questions, which had the quality to check the acquisitions determined in the chemistry teaching program by Turkish Ministry of National Education's (MNE) secondary level $10^{\text {th }}$ grade classes, was prepared during the development process of the Mixtures Achievement Test (MAT) prepared by the researcher who was related to the mixtures subject. In the first stage of each test question, the correct answer was asked; and in the second stage, the rationale for the answer was demanded. Opinions of subject matter experts were asked for the test validity and adjustments were realized in line with the received opinions. Before the testing of the research group, the test was applied on another 25 -student $10^{\text {th }}$ grade class of the same school for pilot study, and the test was put into final form in accordance with the results acquired from the application. Questions whose both answers and rationale were correct were deemed to be answered correctly. The test's reliability co-efficient was calculated as 0,875 for the pilot application and 0,910 for the research group.

Example: Which of the following is not a mixture?
a) Water flavored with vinegar
b) Iced lemonade
c)Iced Water
d)Eau de cologne
e) Anti-freeze 
Rationale:

1. There is no certain ratio among the matters constituting the mixture.

2. Mixtures do not have certain chemical formulas.

3. Chemical properties of the matters composing the mixture do not change.

4. There are different types of molecules in the structure of the mixture.

5. Melting and boiling points of the mixtures are not constant.

\subsection{Application Steps}

Guide material to be used in the research was prepared by the researcher. The prepared and applied guide material was cared to have the content and level of interpretability at the end of the experiments which the students would perform in their lessons. The teacher who would carry out the application was adequately informed on the material and the PBL. After the application of the pre-test, the chemistry topic was discussed through the traditional teacher-centered method in the control group and in accordance with the PBL method in the experimental group. Experimental group students were divided into four homogeneous groups (which were heterogeneous inside) of six students according to the pretest results, and they were informed by the course teacher on the PBL method. Pretest, PBL briefing, application and posttest lasted for 16 course hours (1 course hour equals to 45 minutes).

\subsubsection{Guide Material}

During the designation and the creation of the below-mentioned problem case and the problem case of the guide material which was explained step by step, it was remarked that they were associated with their daily life. During the presentation of the problem case, students should not have much information with regard to the topic, so that they can be encouraged to gather information, to question the problem case and to think adequately on the cause and effects. Besides, problem should be able to be changed, to be developed and to pave a new path for investigations (Torp \& Sage, 2002).

\subsubsection{Problem Case}

One of the objectives of the basic chemistry course is contributing to students' upbringing as sensible and conscious individuals for the protection of their own health and environment, by associating the information and skills they gained from the chemistry course to different circumstances about life. Environmental problems directly related to human life are highly important. It is also necessary to bring students up who have high awareness for the environmental pollution problems which often have direct effects on human life.

Mert from the experimental group is an environmentally-conscious and hardworking student. There were many unimproved streams in his home city (For instance, Kurbağalıdere in Istanbul province's Kadıköy district). Fluid flowing in the streams was mud-like and blurry, and there were greasy layers over the surface. As this environmental problem and pollution disturbed Mert, he narrated this situation to his chemistry teacher and asked help for the solution of this environmental problem. Having learned the situation, the chemistry teacher said "OK kids, next week we will discuss the unit on mixtures. Let's form groups in our class and do some research on how we can solve the problem."

\subsubsection{Students Develop a Plan}

Students define the problem actively, determine what they know and what they need to know based on their previous knowledge experience. Students are encouraged for determining what they need to understand in order to solve the problem. Then, through discussions, students identify the strategies and studies for solving the problem. This process ensures revealing the students' preliminary information and enables them to make correlations with them. Ill-structured problems urge them to define what they know and what they need to know in order to solve the problem case (Torp $\&$ Sage, 2002; Boud \& Feletti, 1991).

\subsubsection{Process Steps}

Mert's teacher started to plan what each group would do for solving the problem, through separating 24 students of the experimental group into homogenous four groups in accordance with the result of the pretest. The first group would take waste samples from stream's different parts and would investigate what kinds of pollution there were. Other groups would examine the taken samples through feasible experiments in the school's laboratory.

The first group students took four identical capped glass bottles from the school's laboratory and numbered them. Then, they took samples from different parts of the stream and investigated the environment. The teacher asked the first group students to examine full bottles roughly, present their observations to the class and to make explanations through giving daily life examples on mixtures. 
In the next lesson, the teacher asked the second group students to weigh the full bottles on scales and to write the weighing results on the board. Then, he asked them to weigh and put in four beakers the following respectively: $5 \mathrm{~g}$ salt in the $1^{\text {st }}$ beaker; $5 \mathrm{~g}$ salt and $5 \mathrm{~g}$ oil in the $2^{\text {nd }}$ beaker; $50 \mathrm{~g}$ salt, $5 \mathrm{~g}$ sulphur powder in the $3^{\text {rd }}$ beaker; $50 \mathrm{~g}$ salt, $5 \mathrm{~g}$ sulphur powder and $5 \mathrm{~g}$ iron powder in the $4^{\text {th }}$ beaker. And he wanted them to stir with stick by adding water into them. He instructed the group to make observations after putting the obtained mixtures into volumetric flasks of $0,5 \mathrm{lt}$ and adding water over it until the total volume reaches up to $0,5 \mathrm{lt}$. The teacher also demanded them to explain their observations through rough drawings on the board.

The teacher wanted the third group to set up the necessary mechanisms; to heat pure water, salted water and one of the samples received from factory waste carefully; to measure the temperature with a thermometer at certain time intervals; to record the results; to draw thermal graphics against time and to compare their boiling points in the graphics. Similarly, the group was asked to measure, at certain intervals, the melting temperatures of pure ice, salted ice (salt solution prepared by the previous group was frozen) and one of the samples received from factory waste; to record the results; to draw thermal graphics against time and to make explanations by comparing their freezing points in the graphics.

The fourth group was instructed to separate the sediments by filtering the sample and in case there were metals in the sediments which remained undissolved in the fluid, then they are asked to extract these metals by means of a magnet. In order to understand whether there is solute inside the sample \#1 or not, they were instructed to perform distillation through distillation method and explain the result. Additionally, if different phases were formed in the filtrate, they were asked to separate the phases from each other with the help of a separating funnel (a separating funnel is a glass instrument which enables extraction of liquid-liquid heterogeneous mixtures) and to explain the results.

\subsection{Analysis of Data}

In the research, the SPSS 15.0 program was used for the analysis of data. The significance level in the statistical processes which were used in the research was acknowledged as minimum 0.05 .

\section{Findings}

While the preliminary data of the research were being specified, MAT prepared by the researcher was applied as the pretest in order to define whether control and experimental group students met the assumption about their readiness level for the mixtures unit of high school 10th grade chemistry course. Acquired data are presented in Table 1.

Table1. Results of independent group T-test for control and experimental groups' pretest mixtures achievement test

\begin{tabular}{llllll}
\hline Group & $\mathrm{N}$ & $\mathrm{X}$ & $\mathrm{SS}$ & $\mathrm{T}$ & $\mathrm{P}$ \\
\hline Control & 24 & 10,46 & 1,47 & \multirow{2}{*}{0,800} & \multirow{2}{*}{0,427} \\
Experimental & 24 & 11,60 & 1,59 & & \\
\hline
\end{tabular}

Before the application, no significant difference was found between the control and experimental groups. ( $p>0.05$, Table $1)$.

After the application of pretest, the mixtures topic was discussed through teacher-centered traditional method in the control group, and through the PBL method in the experimental group in accordance with the guide material prepared by the researcher. Following the application, achievement test on mixtures was executed on the control and experimental groups; and a significant difference between the groups was detected in favor of the experimental group (Table 2)

Table 2. Results of independent group T-test for control and experimental groups' posttest mixtures achievement test

\begin{tabular}{llllll}
\hline Group & $\mathrm{N}$ & $\mathrm{X}$ & $\mathrm{SS}$ & $\mathrm{T}$ & $\mathrm{P}$ \\
\hline Control & 24 & 17,920 & 3,390 & \multirow{2}{*}{$-3,897$} & \multirow{2}{*}{0,001} \\
Experimental & 24 & 22,040 & 4,641 & \\
\hline
\end{tabular}

In consequence of the statistical analysis of posttest realized after the application, a significant difference in favor of the experimental group was found in the achievement test on mixtures topic. $(\mathrm{p}<0.05$, Table:2).

After the examination of the first group's samples, group's spokesperson explained to the class the result they concluded, under the guidance of the course teacher. Expressing that they, at first, examined the bottles in terms of their color, the spokesperson stated "the appearance of one of the bottles was loud and clear; the other three bottles were blurry compared to the first one and their weights were different from each other, too." He also added that the first bottle seemed to convey only one single matter, that a greasy layer existed over the second bottle's fluid and this greasy layer did not mix with the bottom section, that there were floating and even macroscopical matters inside the third bottle, and that the fourth bottle was quite heavy compared to the others and it conveyed subsiding muddy matters." With these findings, concepts like "homogeneous mixture, heterogeneous mixture, suspension and emulsion" were comprehended and it was concluded that acquisition of "classifying mixtures, which the students encounter in daily life, according to different quantities" was gained. 
The second group weighed the bottles full of samples on a scale and wrote their weight differences on the board, then spokesperson of the second group explained: "Although sample bottles were identical, we found out that the bottles' weights were different from each other. Bottles with sediments inside were heavier. Density of the dissolved materials should be heavier than water so that weight increases as the sediment quantity increases. The lightest one was the first bottle, while the heaviest one was the fourth bottle where the sediments were abound. We observed that when we increased the solute quantity in the solutions which we prepared in the laboratory and which conveyed different amounts of salt, not only sediments were formed but also the weight of the solution increased. When we added sulphur powder into water, we observed that sulphur powder pended inside the water and did not dissolve". Concepts like "dissolution, solvent, solute, concentration" were figured out with these statements and they gained the acquisition of "student can interpret the statements which give the solute rate."

Spokesperson of the third group concluded his words saying: "we drew a graphic by benefiting from the data which we acquired through setting up the necessary mechanisms in the laboratory environment and we detected via the graphic that the boiling point temperature of pure water is $100^{\circ} \mathrm{C}\left(99,6^{\circ} \mathrm{C}\right)$. Through the drawn graphics, we also detected that boiling point of salted water is approximately $103^{\circ} \mathrm{C}$ and boiling point of the sample taken from the stream is $104^{\circ} \mathrm{C}$. We concluded from these results that the boiling point of the solution was different from that of the solvent. Similarly, while specifying the freezing points through temperature-time graphics, we identified that freezing point of pure water was around $0^{\circ} \mathrm{C}$, and freezing temperatures of salted water and the sample were below $0^{\circ} \mathrm{C}$. Through the graphics, we found out the freezing point of salted water as $-5^{\circ} \mathrm{C}$ and the sample's freezing temperature as $-4^{\circ} \mathrm{C}$." Concepts like "colligative" were learned via these findings and the acquisition of "student can interpret solutions' characteristics which are related to daily life" was acquired.

Spokesperson of the fourth group expressed "we separated the greasy layer on the top of the sample bottle \#2 from the bottom section with the use of a separating funnel and we detected that densities of the fluids were different. We extracted the residuum which remained undissolved inside the mixtures by filtering the samples \#3 and \#4 with the help of funnel and filter paper. We observed how the mixtures were resolved with the help of magnet, by extracting the matters in the collected residuum which could be attractable through a magnet. By setting up the necessary mechanism in order to distill sample \#1 which seemed to be a single matter and by observing the decomposition of the dissolved matters inside it, we also learned how matters would be refined." Concepts like "filtering, distillation, forming phases" were learned with these explanations and the acquisition of "student discovers the mixture decomposition techniques which are used in industry and health areas" was realized.

\section{Discussion and Conclusion}

The problem sentence of the research is expressed as "according to the pretest and posttest results, is there a significant difference between the students' successes in the topic of mixtures, when the problem-based learning (PBL) method and teacher-centered traditional methods are compared?". As a result of the analyses, experimental group's average of understanding the mixtures topic in the posttest is significantly higher than that of the pretest. Education provided for the experimental group via PBL had a positive effect on their learning of mixtures topic. Same results were also valid for the control group students who had education through teacher-centered traditional methods. But a significant difference in favor of the experimental group is discussed with regard to the posttest mixture-themed achievement test of experimental and control groups (Table 2). PBL method has a more positive effect in learning of mixtures, compared to the traditional method.

In literature; Tarhan, Kayal1, Urek and Acar (2008) stated in their research titled "Problem-based learning in 9th grade chemistry class: Intermoleculer forces" that PBL method is more effective in removing misconceptions of students; Tüysüz, Tatar and Kuşdemir (2010) expressed in their study "Review of the effect of the problem-based learning on students' achievement and attitude in chemistry (the unit of gases)" that, when the chemistry achievements of experimental and control groups were compared, there was a significant statistical difference in favor of the experimental group on which PBL method was used; Çelik, Eroğlu and Selvi (2012) referred in their research titled "the effect of problem-based learning approach in science education on students' academic achievement and attitudes towards science and technology course" that realizing activities based on PBL approach had a positive effect on the academic achievements of students in Matter and Heat topic; Özeken and Yıldırım (2011) expressed in their research named "the effect of problem-based learning method in teaching acid-base subject on science teachers' academic success" that, compared to the traditional teaching methods, students were more successful in acid-base topic when PBL method was used; Kelly and Finlayson (2007) figured in their study "providing solutions through problem-based learning for the undergraduate 1 year chemistry laboratory" that PBL method developed practical and life-long learning skills as well as scientific content knowledge and understanding over the effectiveness of the traditional laboratory courses, and it provided an environment conducive to meaningful and deep learning. Thereby, studies in the literature also support the finding of our study that PBL is an effective method in learning the chemistry subjects. 
Problem-based learning approach is recommended to be used in formal education institutions and in high school chemistry teaching due to the fact that the method is thought to raise students' skills like "bringing the problem or problems which students may encounter in daily life into the class environment as scenarios, defining the problem in the scenario, structuring in their minds information regarding the problem and its solution, developing ways out for the problem and coming out with a solution."

\section{References}

Akınoğlu, O., \& Eren, C. D. (2013). Effect of Problem-based Learning (PBL) on Critical Thinking Disposition in Science Education. JEPE, 14(3), 1353.

Barrows, H. S., \& Tamblyn, R. M. (1980). Problem-Based Learning-And Approaeh To Medical Edueation. New York, Springer Publishing Company.

Bayrakçeken, S., Doymuş, K., \& Doğan, A. (2013). İşbirlikli, öğrenme modeli ve uygulanması. Ankara, Pegem akademi.

Boud, D., \& Feletti, G. (1991). The Challenge of Problem Based Learning. London, Kogan Page.

Çelik, E., Eroğlu, B., \& Selvi, M. (2012). Fen eğitiminde probleme dayalı öğrenme yaklaşımının öğrencilerin akademik başarısı ile fen ve teknoloji dersine yönelik tutumlarına etkisi. Kastamonu Eğitim Dergisi, 20(1), 187-202.

Chin, C., \& Chia, L. (2004). Problem-based learning: using students' questions to drive knowledge construction. Science Education, 88(5), 707-727. http://dx.doi.org/10.1002/sce.10144

Dahlgren, M. A., \& Öberg, G. (2001). Questioning to learn and learning to question: structure and function of problem-based learning scenarios in enviromental science education. Higher Education, 41, 263-282. http://dx.doi.org/10.1023/A:1004138810465

Demircioglu, H., Demircioglu, G., \& Ayas, A. (2006). Hikayeler ve kimya öğretimi. H.Ü. Eğitim Fakültesi Dergisi, 30, 110-119.

Doymuş, K., Şimşek, Ü., \& Bayrakçeken, S. (2004). İşbirlikli Öğrenme Yönteminin Fen Bilgisi Dersinde Akademik Başarı ve Tutuma Etkisi. Türk Fen Eğitimi Dergisi, 1(2), 103-115.

Duch, B. J. (2001). Writing problems for deeper understanding. In Duch, B. J., Groh S. E., \& Allen D. E. (Eds.), The power of problem-based learning: A practical "How to" for teaching undergraduate courses in nay discipline (pp. 47-53). Sterling, VA: Stylus.

Kaptan, F., \& Korkmaz H. (2001). Fen eğitiminde probleme dayalı öğrenme yaklaşımı (Problem-based learning approach in science education). Hacettepe Üniversitesi Eğitim Fakültesi Dergisi, 20, 185-192.

Kelly, O. C., \& Finlayson, O. E. (2007). Providing solutions through problem-based learning for the undergraduate 1 year chemistry laboratory. Chemistry Education Research and Practice, 8(3), 347-361. http://dx.doi.org/10.1039/B7RP90009K

Koray, Ö., Akyaz, N., \& Köksal, M. S. (2007). Lise öğrencilerinin "çözünürlük" konusunda günlük yaşamla ilgili olaylarda gözlenen kavram yanılgıları. Kastamonu Eğitim Dergisi, 15(1), 241-250.

Mc Donnell, C., O'Connor, C., \& Seery, M. K. (2007). Developing practical chemistry skills by means of student-driven problem-based learning mini-projects. Chemistry Education Research and Practice, 2007, 8(2), 130-139. http://dx.doi.org/10.1039/B6RP90026G

Mierson, S., \& Parikh, A. A. (2000). Stories from the field: Problem-based learning from a teacher's and a student's perspective. Change, 32(1), 20-27. http://dx.doi.org/10.1080/00091380009602705

Özeken, Ö. F., \& Yıldırım, A. (2011). Asit-Baz Konusunun Öğretiminde Probleme Dayalı Öğrenme Yönteminin Fen Bilgisi Öğretmen Adaylarının Akademik Başarıları Üzerine Etkisi. Pegem Eğitim ve Öğretim Dergisi, 1(1), 33-38.

Springer, L., Stanne, M. E., \& Donovan S. S. (1999). Effects of small-group learning on undergraduates in science, mathematics, engineering, and technology: A meta-analysis. Review of Educational Research, 69(1), 21-51. http://dx.doi.org/10.3102/00346543069001021

Tarhan, L., Kayali, H. A., Urek, R. O., \& Acar, B. (2008). Problem-based learning in 9th grade chemistry class: Intermoleculer forces. Res. Sci. Educ., 38, 285-300. http://dx.doi.org/10.1007/s11165-007-9050-0

Torp, L., \& Sage, S. (2002). Problems as possibilities: Problem-based learning for K-16 education (2nd ed). Alexandria, VA: ASCD.

Tüysüz, C., Tatar, E., \& Kuşdemir, M. (2010). Probleme dayalı öğrenmenin kimya dersinde öğrencilerin başarı ve tutumlarına etkisinin incelenmesi. Mustafa Kemal Üniversitesi sosyal bilimler enstitüsü dergisi, 7(13), 48-55

This work is licensed under a Creative Commons Attribution 3.0 License. 